\title{
The microbiological condition of public air in the city during autumn and winter
}

\section{Stan mikrobiologiczny powietrza miejskiego w miejscach publicznych w okresie jesienno-zimowym}

\author{
Wioletta Adamus-Białek, Aneta Filipiak, Monika Wawszczak, Aleksandra Woźniak, Stanisław Głuszek \\ Department of Surgery and Surgical Nursery with Laboratory of Genetics, Faculty of Medicine and Health Sciences, \\ Jan Kochanowski University, Kielce, Poland \\ Head of the Department: Prof. Stanisław Głuszek MD, PhD
}

Medical Studies/Studia Medyczne 2019; 35 (3): 203-209

DOI: https://doi.org/10.5114/ms.2019.88418

Key words: microbiological air pollution, outdoor bacteria, indoor bacteria.

Słowa kluczowe: mikrobiologiczne zanieczyszczenie powietrza, bakterie pomieszczeń, bakterie na wolnym powietrzu.

\begin{abstract}
Introduction: Microorganisms live in most environments, and one of the most common is air. Bacteria, viruses, and fungi occur as bioaerosols, which allows them to spread. Airborne bacteria are potentially pathogenic, especially in areas densely populated by people.

Aim of the research: To analyse the microbiological air pollution in different public places - busy streets, a city park, a cinema, and a pharmacy, in Kielce, during autumn and winter.

Material and methods: The total number of bacteria was estimated based on the sedimentation method. The microbiological condition of air was compared to the standardised Polish norm. Additionally, the macroscopic (bacterial colony) and microscopic (Gram-stained bacterial cells) methods were used for bacterial differentiation.

Results: Most of the air samples did not exhibit contamination, although the detected cases of significant microbiological pollution do pose a threat to public health. The air on the streets revealed the highest microbial contamination, and the lowest levels of microbes were found in the park. The influence of temperature and population density on the bacterial prevalence in the air has been proven. Despite low air temperatures, the amount of bacteria in most cases was close to the average pollution level. It was also observed that in the pharmacy, the glass separating customers and staff did not reduce the number of bacteria on either side.

Conclusions: Special attention should be paid to places that can significantly influence the spread of pathogens due to large population (e.g. a cinema) or the presence of sick people (e.g. a pharmacy). Air should be monitored in such places.
\end{abstract}

\section{Streszczenie}

Wprowadzenie: Mikroorganizmy stwierdza się w prawie każdym środowisku, szczególnie powszechnie w powietrzu. Bakterie, wirusy i grzyby występują w postaci bioaerozoli, co pozwala im się przemieszczać. Bakterie przenoszone przez powietrze mogą należeć do patogennych grup, zwłaszcza w miejscach często uczęszczanych przez ludzi.

Cel pracy: Analiza mikrobiologicznego zanieczyszczenia powietrza w różnych miejscach publicznych, takich jak ruchliwe ulice, park miejski, kino i apteka.

Materiał i metody: Ogólną liczbę bakterii określono metodą sedymentacji. Stan mikrobiologiczny powietrza porównano z normą polską. Dodatkowo do różnicowania bakterii zastosowano metody makroskopowe (obserwacja kolonii bakterii) i mikroskopowe (obserwacja komórek bakterii wybarwionych metodą Grama).

Wyniki: W większości próbek powietrza nie stwierdzono zanieczyszczenia, chociaż wykryte przypadki znacznego zanieczyszczenia mikrobiologicznego stanowią zagrożenie dla zdrowia publicznego. W powietrzu na ulicach odnotowano najwyższy poziom zanieczyszczenia mikrobiologicznego, najmniej drobnoustrojów występowało w parku. Dodatkowo wykazano wpływ temperatury i zaludnienia na wysteppowanie bakterii w powietrzu. Mimo niskich temperatur powietrza liczba bakterii w większości przypadków była bliska średniego poziomu. Zaobserwowano również, że w aptece szyba dzieląca klientów i personel nie wpływa na zmniejszenie liczebności bakterii po obu stronach.

Wnioski: Należy zwrócić szczególną uwagę na miejsca, które mogą znacznie wpływać na rozprzestrzenianie się patogenów ze względu na duże zaludnienie (np. kino) lub obecność osób chorych (apteka). W takich miejscach powietrze powinno być monitorowane. 


\section{Introduction}

Natural air pollutants such as fungi, bacteria, and viruses are ubiquitous in the environment. The contamination of air depends on many various factors, for example the density of population, industrialisation of a given area, and fertilisation of surrounding soils. The presence of microorganisms in the air also depends on climatic conditions, such as temperature, humidity, precipitation, and wind. Due to the unstable and abiotic parameters, the air is only a transmission path for microorganisms [1-4]. They can be spread by natural air movements, winds, rainfall, animal's and human's activities [1, 5-7]. Bacteria adapted to air spreading have specific properties such as an optimal shape and size of the cells, the ability to form spores, metabolic properties, the ability to form biofilm, and pigment production [8]. Bioaerosols are the primary pathway of microorganisms spread in the environment. Bioaerosols are defined as airborne particles of biological origin such as bacteria, viruses, fungi, and their fragments like DNA or metabolites (endotoxin and mycotoxin). It is obvious that microparticles contained in bioaerosols may cause serious diseases like allergy, toxic reactions, and infections [9]. Most bioaerosols are non-pathogenic and only cause infections or illness in people with impaired or susceptible immune systems [10]. Microorganisms are ubiquitous in the atmosphere, and their concentrations typically range from $10^{4}$ to $10^{6}$ cells $/ \mathrm{m}^{3}$. The amount of bacteria in the air may be far higher in proximity to point sources like wastewater treatment plants, fertilised fields, and farms [11]. Within bioaerosols the most common microorganisms are saprophytic bacteria: Micrococcus spp., Achromobacter spp., and Bacillus spp. However, pathogenic bacteria like Klebsiella pneumoniae, Pseudomonas aeruginosa, Mycobacterium tuberculosis, Legionella pnaumophila, Pseudomonas putida, and Proteus vulgaris may occur in bioaerosols [12-16]. Micromolecules of bioaerosol can be easily inhaled to the respiratory tract and cause a number of health complications; therefore, air contamination monitoring should be under the scope of epidemiological studies and public health [17].

\section{Aim of the research}

The aim of this study was to estimate the microbiological quality of air in the city during autumn and winter. The analysis included various outdoor and indoor public places located in Kielce, the capital of Świętokrzyskie voivodeship.

\section{Material and methods}

\section{Sampling}

Air samples were collected in five different places in Kielce in the Świętokrzyskie Voivodeship: two busy streets, a city park, a pharmacy, and a cinema. Two measurement points were placed on $50 \mathrm{~cm}$ and $150 \mathrm{~cm}$ from the ground next to busy streets in the centre of the city - Solidarności Av. and Ogrodowa St. The next place was located by an alley in Stanislaw Staszic City Park. In the pharmacy, four measurement points were located opposite each other, two from the clients' side and two from the seller's side. Additionally, the air in the cinema was analysed at five measurement points - the auditorium, two entrance gates, the projector shelf, and an anteroom. The analyses were carried out in the autumn and winter in the years 2010-2012. The sampling was repeated on two plates in two independent experiments on each measurement point.

\section{Microbiological analysis}

The total number of aerobic bacteria was calculated by Koch sedimentation method. Open Petri dishes with agar were distributed at the processing areas and exposed for $10 \mathrm{~min}$. The Petri dishes were closed and incubated at $37^{\circ} \mathrm{C}$ for $24-48 \mathrm{~h}$. The mesophilic bacteria were cultured on enriched agar medium (Biocorp), and the mannitol-positive Staphylococcus sp. were cultured on Mannitol salt agar (Biocorp). The degree of contamination was determined based on the total number of CFUs (colony forming units) in one cubic metre of air according to the standardised formula in Polish standard PN-89-Z-04111/02: $A=\left(a \times 10^{4}\right) /\left(p \times r^{2}\right.$ $\times 0.2 \times t$ ), where: $A-$ number of bacteria /microscopic fungi in $1 \mathrm{~m}^{3}$ of atmospheric air, $a$-medium number of colonies on the Petri dishes, $p \times r^{2}-$ the surface of the Petri dish $\left(\mathrm{cm}^{2}\right), \mathrm{t}$ - exposure time (min), 0.2 - conversion factor of the exposure time.

Additionally, the grown bacterial colonies were analysed by macroscopic (visual assessment) and microscopic (Gram staining) observations. Bacteria were classified into Gram-positive or Gram-negative strains, with specific cell shapes.

\section{Statistical analysis}

The obtained results were presented on the figures as arithmetic means and standard deviations prepared by Graph Pad Prism version 6 Software (San Diego, CA, USA). The nonparametric T-test or MannWhitney un-paired two-tailed tests were used for statistical analysis. Differences with a $p$-value of $<0.05$ were considered significant.

\section{Results}

The obtained results were distinguished into two different agents: outdoor and indoor public places. These are the areas used most by people during autumn and winter. Outdoor analysis included two busy streets and a city park, indoor analysis included a pharmacy and a cinema. The microbiological analysis considered the presence of mesophilic aerobic bacteria in atmospheric air. The number of fallen, grown colonies were compared to the number of bacteria in 


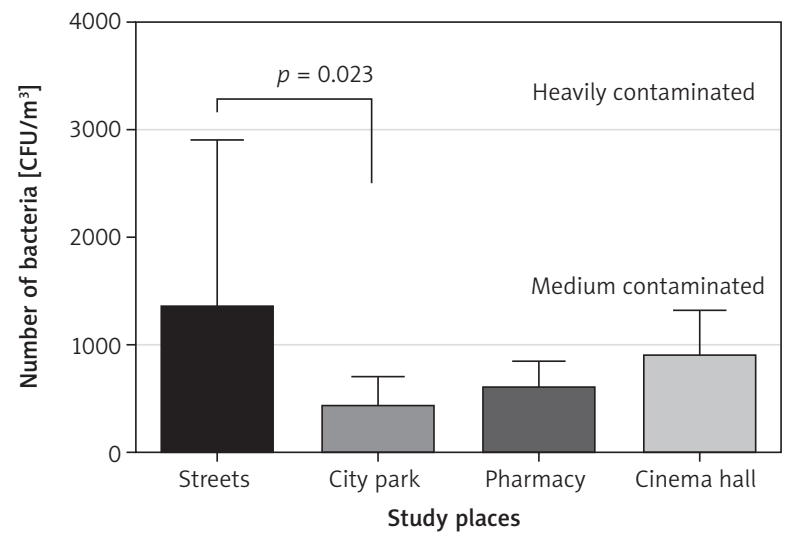

Figure 1 . The average total number of bacteria in the air $\left(\mathrm{CFU} / \mathrm{m}^{3}\right)$ of different public places of the city (Kielce, Poland) in autumn and winter with reference to the degree of contamination (medium and heavily) according to the Polish standard. The statistically significant difference $(p=0.023)$ between the total number of bacteria detected on the streets and in the city park was determined by Mann-Whitney un-paired two-tailed tests (Graph Pad Prism v. 6 Software, San Diego, CA, USA)

$1 \mathrm{~m}^{3}$ in the air in the study places according to the formula standardised in the Polish norm. In the case of the outdoor sampling the air was highly contaminated only once, and in $15.7 \%$ of samples the results revealed medium contamination of air. This pollution concerned only the measurement points located next to the road. In the case of indoor sampling, the air reached the level of medium microbiological pollution only once: in the cinema hall in the autumn. The number of bacteria in the winter was lower in comparison to the autumn in all study places, but the differences were not statistically significant, with the exception of cinema samples. The medium total number of bacteria in $1 \mathrm{~m}^{3}$ of air samples during autumn and winter period are presented in Figure 1. This observation revealed a statistically significant lower number of bacteria in the city park compared to the streets. The indoor places included the presence of people during the analysis in the pharmacy and cinema. A lower number of bacteria were detected in the pharmacy, but the difference was not significant. Additionally, the influence of air temperature (Figure 2) and presence of people (Figure 3) on the number of bacteria in the air has been proven. A statistically significant increase in the number of bacteria was recorded at a temperature of $12^{\circ} \mathrm{C}$, and this value was on average five times higher than at temperatures in the range -8 to $+8^{\circ} \mathrm{C}$. There was no difference in the number of bacteria in the range -8 to $+8^{\circ} \mathrm{C}$ of air temperature. Likewise, a statistically significant increase in the number of bacteria was recorded in the cinema auditorium during the screening of a film, where a lot of people were present in comparison to the measurement points where almost no people were present at

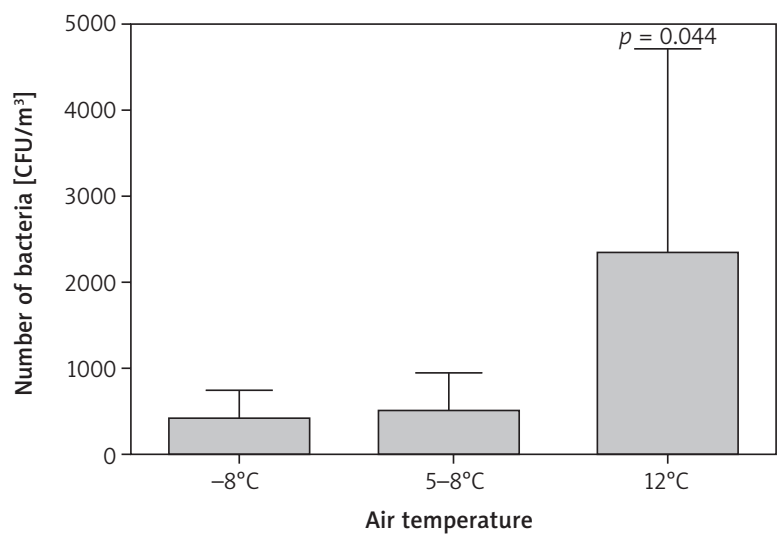

Figure 2. The average total number of bacteria in the air $\left(\mathrm{CFU} / \mathrm{m}^{3}\right)$ on the measurement points of the street compared to the air temperature. The statistically significant difference $(p=0.044)$ of the total number of bacteria detected at $12^{\circ} \mathrm{C}$ compared to the lower temperatures (from $-8^{\circ} \mathrm{C}$ to $+8^{\circ} \mathrm{C}$ ) was determined by Mann-Whitney un-paired two-tailed tests (Graph Pad Prism v. 6 Software, San Diego, CA, USA)

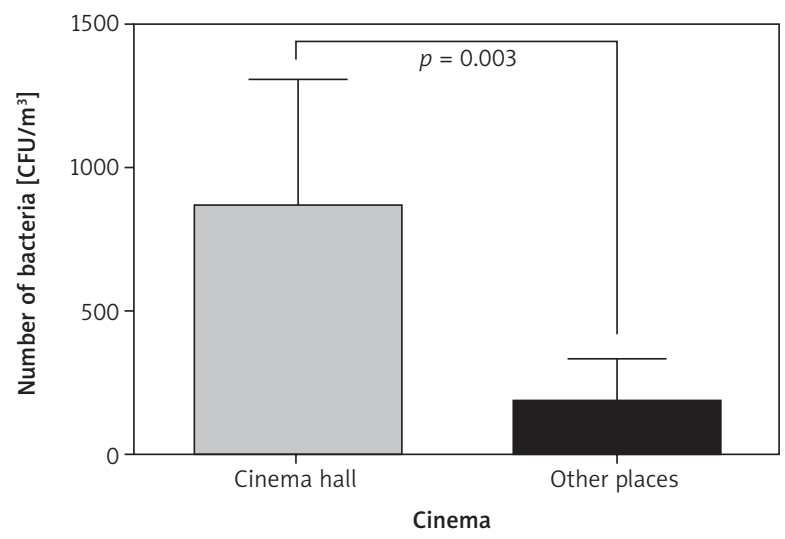

Figure 3. The average total number of bacteria in the air $\left(\mathrm{CFU} / \mathrm{m}^{3}\right)$ of the cinema. The statistically significant difference $(p=0.003)$ between the total number of bacteria detected in the cinema auditorium and other places was determined by nonparametric $T$-test un-paired two-tailed (Graph Pad Prism v. 6 Software, San Diego, CA, USA)

all. Furthermore, we observed also that the glass on the sales counter, which separates the customers from the sellers, did not have any influence on the number of bacteria identified in the air around the people. An average, 11 customers and two sellers were present during the sampling. The was no significant difference between the total number of bacteria in the air either side of the measurement points (Figure 4).

Furthermore, we performed Gram staining of isolated, representative, diverse bacterial colonies. Generally, the Gram-negative strains were present more often outdoors and Gram-positive strains were present more often indoors (Figure 5). Among the identified bacteria, 


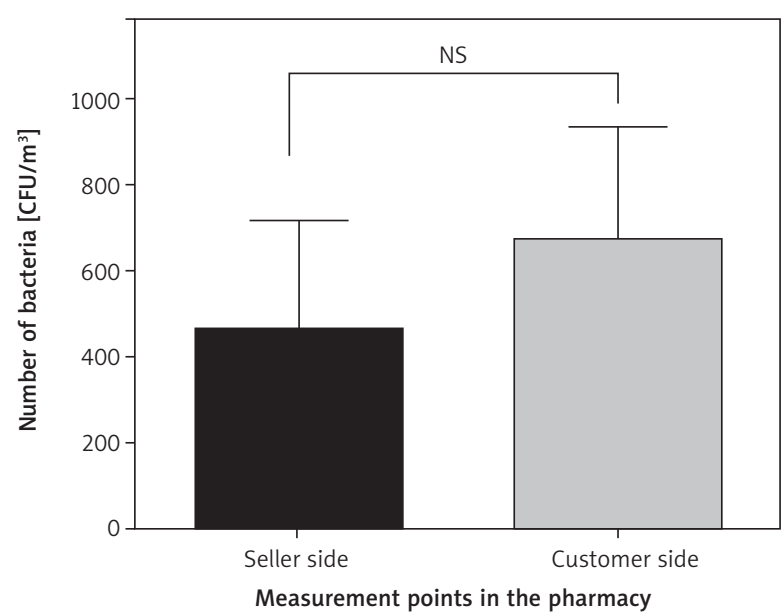

Figure 4. The average total number of bacteria in the air $\left(\mathrm{CFU} / \mathrm{m}^{3}\right)$ of the pharmacy with reference to the measurement points on the salesperson and customer sides. The difference was not statistically significant

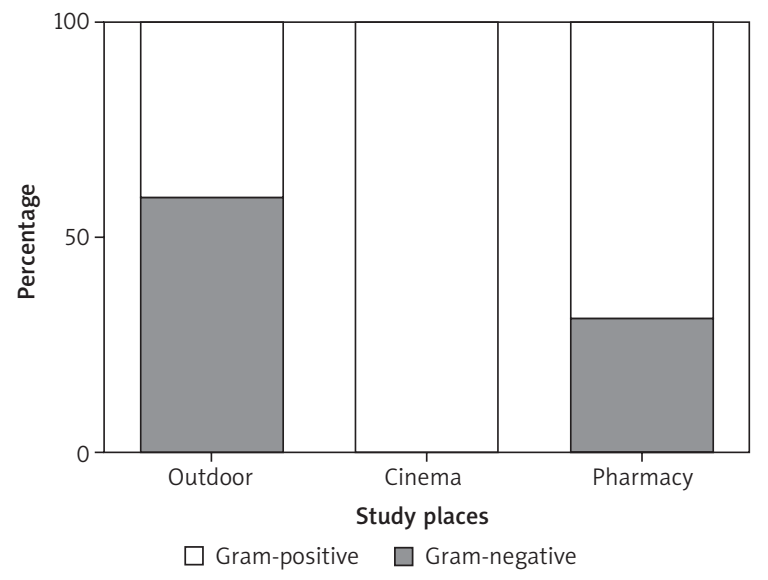

Figure 5. The percentage occurrence of Gram-positive and Gram-negative bacteria in outdoor (streets, city park) and indoor (cinema, pharmacy) places

the round-shaped and bacilli Gram-positive and rodshaped Gram-negative cells were most often observed. These bacteria grew as coloured colonies (red, orange, yellow) or milk-white colonies. The last examination concerned the analysis of mannitol-positive Staphylococcus sp. strains. These bacteria were analysed in the case of Ogrodowa St., the city park, and the pharmacy. In all cases, the mannitol-positive Staphylococcus sp. strains were not identified, the grown bacteria did not change the agar from red to yellow.

\section{Discussion}

Air is well known as a vehicle for the spread of a wide diversity microorganisms, among which human pathogens may also be present. Microorganism transmission via air plays an important role in the ef- fortless and rapid spread of viral, bacterial, and fungal infections $[9,18]$. Bacterial cells and their fragments, fungal spores, and products of microbial metabolism present as organic compounds in each of the three states of matter may be components of bioaerosols [19]. Bioaerosols are complex, highly variable, ubiquitous, natural, or manufactured by people [20]. The biological effects of these bioaerosols depend on their size, concentration, and physio-chemical properties. Because of the micro to nano scale size, these pollutants can easily enter and deposit in many parts of the body via the lungs and circulatory system. Once inhaled, bioaerosols are associated with a wide range of negative health effects (e.g. allergies, infectious diseases, asthma, cancer, and acute toxicity). People permanently interact with the surrounding environmental microbiome through inhalation, dermal contact, or ingestion. Despite the large numbers of microorganisms likely to be present in the environment in highly populated public places, significant harm from this exposure is rare. The epidemiological studies of microbial contaminants in the air are rarely carried out [20-25].

The aim of the study was to analyse the microbial air pollution in public places in the city during the autumn-winter period. The studies focused on different indoor and outdoor places in Kielce such as a city park, busy streets, a cinema, and a pharmacy. The city is located in central-eastern Poland, located in the Swiętokrzyskie Mountains, on the river Silnica. According to data of the Central Statistical Office from 2017, the city has 196,804 inhabitants. It can be concluded that a medium-sized city will reflect a microbial state similar to most Polish cities. The basic analysis included the total number of microbes at the measurement sites according to the Polish standard. In the case of the outdoor locations, only one measurement detected highly contaminated air, and in $15.7 \%$ of samples the results revealed a medium level of air contamination. The most polluted places were located near the most frequented streets in the city. The sources of air pollution are varied and may originate from people, animals, gastronomy, or industry. It is worth noting that in many big cities around the world, street food has become very popular. This type of fast food is extremely heterogeneous, including drinks, meals, and snacks and is sold and consumed on the street. Madueke et al. conducted a study involving microbiological analysis of street food. They showed that all the food samples were contaminated with different bacteria and fungi species, i.e. $S$. $a u-$ reus, Streptococcus sp., Flavobacterium sp., B. cereus, K. pnuemoniae, S. dysenteriae, Micrococcus sp., Pseudomonas sp., Enterobacter sp., E. coli, A. flavus, A. niger, Penicillium sp., Fusarium sp., R. stolonifera, and Mucor sp. [26]. Therefore, it is worth considering that potentially pathogenic microorganisms present in polluted 
air near streets may pass directly to food, also causing various intestinal diseases.

A comparison of the total number of microorganisms in the park and on the busy streets was carried out. The results show a lower number of microorganisms in the city park than on the streets. This may suggest that urban parks with a large number of plants, called by many people the lungs of the city, are the optimal place to rest in relatively fresh air [27]. The obtained results are very interesting because plants are recognized as an important source of airborne microorganisms. It is estimated that leaf surfaces comprise the largest biological surface type on the planet - over a billion square kilometres - and may host up to 108 bacteria per $\mathrm{cm}^{2}$. These leaf-inhabiting microorganisms become airborne during plant processes, i.e. evapotranspiration, as well as by meteorological processes such as rain splash, wind gusts, and thermal plumes. Furthermore, the presence of animals and a large amount of organic matter in the park should increase the amount of microorganisms in the air [24]. However, as results indicate, the microbiological air state in the city park was better than on the streets. The greater number of microorganisms on busy streets may be caused by air circulation due to the agitation of dust particles by driving cars. The raised bioaerosol particles can easily spread in the air, and the absorbed microorganisms have the ability to colonise distant niches. A similar observation in a railway station was described by Patel et al. (2018). They proved the seasonal trends of bacterial numbers, which increased from spring through to winter, while fungal numbers peaked in autumn. The complex influence of factors (passenger numbers, station layout, dust) on contamination levels were suggested [25].

The next aim of the study was to check the correlation between the number of microorganisms and the air temperature in the tested places. During the experiments it was found that the number of bacteria in winter was lower than in autumn in all examined places. Thais observation confirmed that a lower temperature contributes to inhibition of the growth of some microorganisms, especially mesophilic bacteria, which were included in the study [28]. A statistically significant increase of the total number of bacteria was detected on the Ogrodowa St. at a temperature of $12^{\circ} \mathrm{C}$, and this value was approximately five times higher than at temperatures in the range $-8^{\circ} \mathrm{C}$ to $+8^{\circ} \mathrm{C}$ (Figure 2). Similar results were obtained by M. F. Yassin and S. Almouqatea. They examined four different outdoor and indoor locations. During their experiments 26 groups of bacteria and fungi, either of human or environmental origin, were detected. The indoor and outdoor bioaerosol concentrations measured during spring were significantly higher compared to the measurements during winter [22]. This outcome proves that higher temperatures give the chance for better development of microorganisms. It would be interesting to conduct research in the same places during the summer. Based on the results obtained so far, probably the number of bacteria at this time of year would be higher.

As a reference point and an important element of air quality for public health, the air inside the buildings of public interest was investigated. The microbiome of indoor air depends on several factors, including the household crowding, hygienic standards and mechanical movement within the enclosed space [22]. For the indoor sampling, a medium level of microbiological pollution was revealed in the cinema auditorium in autumn, and the total number of bacteria was statistically significantly higher in comparison to other places where people were absent (Figure 3). This pollution level can be determined by the presence of a large number of people in the cinema auditorium and their contact with the seats. People also bring their overclothes, which may contribute to the increased amount and diversity of microorganisms in this part of the cinema. A similar observation was provided by Kawasaki et al. (2013). They detected a high number of airborne bacteria in a railway station and it was especially high in summer. They concluded that the number of railway customers, not humidity, was the main factor affecting the concentrations of bacteria [29]. The next exanimed building of public interest was a pharmacy. It can be assumed that the pharmacy is usually frequented by sick people who are a potential source of pathogens. Conducted research shows that the presence of dividing glass between the customers and sellers did not have any influence on the total number of bacteria, and there were no significant differences between the number of bacteria in the air on either side (Figure 4). The results suggest that the use of protective glass in pharmacies does not fully protect the sellers against pathogens that can be spread by customers. Therefore, a special focus must be placed on microbial air surveillance in places with special importance. Not only the protection of staff but also care of the materials and medicines prepared in the pharmacy is important. For this reason, public places should have environmental control procedures that can help to reduce the spread of microorganisms, especially pathogens [30]. Similarly, the importance of the microbiological analysis of the air in places with special requirements was presented by Luksamijarulkul and Pipitsangjan (2015). They revealed high microbial contamination (bacterial and fungal) in the air in ambulances during services as well as on medical instrument surfaces [31]. Microbiological analysis of the air in various public places has been conducted by other authors. Also, air conditioners and hand dryers in washrooms can be a source of microbial pathogens in buildings [32, 33].

Finally, the analysis took into account the presence of Gram-positive and Gram-negative bacteria in 
the studied places. The results suggest that Gram-positive bacteria were present more often in indoor places such as the pharmacy or cinema, which is probably indicative of human-borne contamination. On the other hand, the rod-shaped Gram-negative bacteria were more often identified outside - on the streets and in the park, which may suggested faecal contamination from animals, and some of these bacteria could be dangerous for human health [26]. Among the identified Gram-positive bacteria there were many roundshaped cells, which could suggest the occurrence of Staphylococcus sp., commonly present on the skin surface and upper respiratory tract in humans. Staphylococci are indicators of sanitary air pollution, and their appearance may indicate the presence of pathogenic bacteria. These bacteria may spread in the air with the calloused epidermis and can survive in the air for up to several days. They pose a threat both to immunocompetent persons as well as to those whose immune system is impaired. Especially dangerous strains can be strains resistant to antibiotics, such as methicillin-resistant Staphylococcus aureus (MRSA) [23, 34]. The presence of these bacteria were analysed in the case of the city park, a street (Ogrodowa St.), and the pharmacy. In all cases no mannitol-positive staphylococci were observed, which are important from a clinical point of view. However, it should be mentioned that the identified mannitol-negative colonies are potentially pathogenic to humans. These bacteria may have other abilities, e.g. resistance to antibiotics, which contributes to the increased pathogenicity of these microorganisms. For this reason, contact with such pathogens in the air can lead to various infections. Similar studies have been published by Kubera et al. They examined microbiological air quality in two different kindergartens and found high levels of air pollution with mannitol-positive staphylococci. The levels of these microorganisms significantly exceeded the acceptable standards. Moreover, the antibiotic resistance of isolated strains was analysed. The results showed that all tested strains were resistant to penicillin and gentamycin. The high percentage of antibiotic-resistant staphylococci proves that systematic microbiological examinations of indoor air and further research are needed to help identify biological factors that can affect the health of people in public spaces [35].

It is well known that air pollution monitoring is an extremely important aspect for epidemiology. Many sources of literature present extensive air analysis of diverse environments like for example dust, which is a component of bioaerosols [36], landfills [37], hospitals, and the Earth's stratosphere and troposphere [38]. However, studies of the sanitary conditions of city air are less common. Controlling the microbiological composition of the air, as well as taking care to preserve its purity, can contribute to improving the quality of people's lives. An important aspect is also to pay attention to the air purity inside buildings, where the low air flow can cause accumulation of pathogens.

\section{Conclusions}

It has been shown that the number of bacteria in public city places may be influenced by climatic conditions, such as temperature and the presence of people and traffic. Most of the air samples did not exhibit contamination, although the detected cases of significant pollution pose a microbiological threat to public health. The sanitary condition of the air in the pharmacy should be further investigated.

\section{Acknowledgments}

We would like to thank students Albert Adamczyk, Michałek Michał, Iwona Wojtasik and Szczepan Duralski for assistance during experimental works.

This work was supported under the program of the Minister of Science and Higher Education under the name "Regional Excellence Initiative in 2019-2022 project number: 024/RID/2018/19, financing amount: 11.999.000,00 PLN.

\section{Conflict of interest}

The authors declare no conflict of interest.

\section{References}

1. Błaszczyk MK. Mikroorganizmy w ochronie środowiska. PWN, Warsaw 2007.

2. Kołwzan B, Adamiak W, Grabas K, Pawełczyk A. Podstawy mikrobiologii w ochronie środowiska. Oficyna Wydawnicza Politechniki Wrocławskiej, Wrocław 2005.

3. Libudzisz Z, Kowal K, Żakowska Z. Mikrobiologia techniczna. Mikroorganizmy i środowiska ich występowania. PWN, Warsaw 2012.

4. Prażmo Z, Krysińska-Traczyk E, Skórska C, Sitkowska J, Cholewa G, Dutkiewicz J. Exposure to bioaerosols in a municipal sewage treatment plant. Ann Agric Environ Med 2003; 10: 241-248.

5. Seltzer JM. Biologic contaminants. Occup Med State Art Rev 1995; 10: 1-25.

6. Stach A, Piotraszewska-Pająk A, Stryjakowska-Sekulska M, Filipiak M, Silny W. Outdoor and indoor air microflora of academic buildings in Poznań. Post Dermatol Alergol 2004; 21: 121-127.

7. Douwes J, Dubbeld H, Zwieten L, Al E. Upper airway inflammation assessed by nasal lavage in compost workers: a relation with bioaerosol exposure. Am J Ind Med 2000; 37: 459-469.

8. Venil CK, Zakaria ZA, Ahmad WA. Bacterial pigments and their applications. Process Biochem 2013; 48: 1065-1079.

9. Lee BU. Life comes from the air: a short review on bioaerosol control. Aerosol Air Qual Res 2011; 11: 921-927.

10. Hoseinzadeh E, Samarghandie MR, Ghiasian SA, Alikhani MY, Roshanaie G. Evaluation of bioaerosols in five educational hospitals wards air in Hamedan, during 20112012. Jundishapur J Microbiol 2013; 6: e10704. 
11. Bowers RM, Sullivan AP, Costello EK, Collett JL, Knight R, Fierer N. Sources of bacteria in outdoor air across cities in the Midwestern United States. Appl Environm Microbiol 2011; 77: 6350-6356.

12. Douwes J, Thorne P, Pearce N, Heederik D. Bioaerosol health effects and exposure assessment: progress and prospects. Ann Occup Hyg 2003; 47: 187-200.

13. Michałkiewicz M, Fiszer M. Biologia sanitarna. Ćwiczenia laboratoryjne. Wydawnictwo Politechniki Poznańskiej, Poznań 2003.

14. Flannigan B, Miller JD. Microorganisms in Home and Indoor Work Environments. CRC Press, London 2001; 35-67.

15. Nevalainen A, Pastuszka J, Liebhaber F, Willeke K. Performance of bioaerosol samplers: collection characteristics and sampler design considerations. Atmospher Environm 1992; 26A: 531-540.

16. Pastuszka JS, KyawTha Paw U, Lis DO, Wlazło A, Ulfig K. Bacterial and fungal aerosol in indoor environment in Upper Silesia, Poland. Atmospher Environm 2000; 34: 3833-3842.

17. Pidikiti R, Shamim M, Mallela KMG, Reddy KS, Johansson JS. Expression and characterization of a four-alpha-helix bundle protein that binds the volatile general anesthetic halothane. Biomacromolecules 2005; 6: 1516-1523.

18. Humbal C, Gautam S, Trivedi U. A review on recent progress in observations, and health effects of bioaerosols. Environm Intern 2018; 118: 189-193.

19. Adamus-Białek W, Wawszczak M, Jóźwiak M. Mikrobiologiczne zanieczyszczenie powietrza w centralnej części Gór Świętokrzyskich. Rocznik Świętokrzyski Ser B 2014; 35: 21-33.

20. Srikanth P, Sudharsanam S, Steinberg R. Bio-aerosols in indoor environment: composition, health effects and analysis. Indian J Med Microbiol 2009; 26: 302-312.

21. Garcia-Alcega S, Colbeck I, Coulon F, Ferguson RMW, Dumbrell AJ, Whitby C. Bioaerosol biomonitoring: sampling optimisation for molecular microbial ecology. Mol Ecol Resources 2019; 19: 672-690.

22. Yassin MF, Almouqatea S. Assessment of airborne bacteria and fungi in an indoor and outdoor environment. Int J Environm Sci Technol 2010; 7: 535-544.

23. Wolny-Koładka K, Malinowski M, Pieklik A, Kurpaska S. Microbiological air contamination in university premises and the evaluation of drug resistance of staphylococci occurring in the form of a bioaerosol. Indoor Built Environm 2019; 28: 235-246.

24. Mhuireach G, Johnson BR, Altrichter AE, Ladau J, Meadow JF, Pollard KS, Green JL. Urban greenness influences airborne bacterial community composition. Sci Total Environm 2016; 571: 680-687.

25. Patel KV, Bailey CL, Harding AH, Biggin M, Crook B. Background levels of micro-organisms in the busy urban environment of transport hubs. J Appl Microbiol 2018; 125: 1541-1551.

26. Madueke SN, Awe S, Jonah AI. Microbiological analysis of street foods along Lokoja-Abuja Express Way, Lokoja. Am J Res Commun 2014; 2: 196-211.

27. Jones KR. 'The lungs of the city': green space, public health and bodily metaphor in the landscape of urban park history. Environm History 2018; 24: 39-58.

28. Nedwell DD. Effect of low temperature on microbial growth: lowered affinity for substrates limits growth at low temperature. FEMS Microbiol Ecol 1999; 30: 101-111.
29. Kawasaki T, Kyotani T, Ushiogi T, Lee H. Distribution of airborne bacteria in railway stations in Tokyo, Japan. J Occup Health 2013; 55: 495-502.

30. Napoli C, Marcotrigiano V, Montagna MT. Air sampling procedures to evaluate microbial contamination: a comparison between active and passive methods in operating theatres. BMC Public Health 2012; 12: 594.

31. Luksamijarulkul P, Pipitsangjan S. Microbial air quality and bacterial surface contamination in ambulances during patient services. Oman Med J 2015; 30: 104-110.

32. Hatayama K, Oikawa Y, Ito H. Bacterial community structures in air conditioners installed in Japanese residential buildings. Antonie van Leeuwenhoek 2018; 111: 45-53.

33. Alharbi SA, Salmen SH, Chinnathambi A, Alharbi NS, Zayed ME, Al-Johny BO, Wainwright M. Assessment of the bacterial contamination of hand air dryer in washrooms. Saudi J Biol Sci 2016; 23: 268-271.

34. Shittu A, Lin J, Morrison D. Molecular identification and characterization of mannitol-negative methicillin-resistant Staphylococcus aureus. Diagn Microbiol Infect Dis 2007; 57: 93-95.

35. Kubera Ł, Studzińska J, Dokładna W, Małecka-Adamowicz M, Donderski W. Microbiological air quality in some kindergartens and antibiotic resistance of bacteria of the Staphylococcus spp. genus. Med Pracy 2015; 66: 49-56.

36. Federici E, Petroselli C, Montalbani E, Casagrande C, Ceci E, Moroni B, La Porta G, castellini S, Selvaggi R, Sebastiani B, Crocchianti S, Gandolfi I, Franzetti A, Cappelletti D. Airborne bacteria and persistent organic pollutants associated with an intense Saharan dust event in the Central Mediterranean. Sci Total Environm 2018; 645: 401-410.

37. Cyprowski M, Ławniczek-Wałczyk A, Gołofit-Szymczak M, Frączek K, Kozdrój J, Górny RL. Bacterial aerosols in a municipal landfill environment. Sci Total Environm 2019; 660: 288-296

38. Smith DJ, Ravichandar JD, Jain S, Griffin DW, Yu H, Tan Q, Thissen J, Lusby T, Nicoll P, Shedler S, Martinez P, Osorio A, Lechniak J, Choi S, Sabino K, Iverson K, Chan L, Jaing C, McGrath J. Airborne bacteria in earth's lower stratosphere resemble taxa detected in the troposphere: results from a new NASA Aircraft Bioaerosol Collector (ABC). Front Microbiol 2018; 9: 1752.

\section{Address for correspondence:}

\section{Wioletta Adamus-Białek}

Department of Surgery and Surgical Nursery with

Laboratory of Genetics

Faculty of Medicine and Health Sciences

Jan Kochanowski University

al. IX Wieków Kielc 19 A, 25-317 Kielce, Poland

E-mail: aloiv2002@wp.pl 